\title{
On-farm evaluation of the coconut hybrid, Malayan Yellow Dwarf $x$ Vanuatu Tall for tolerance to the lethal yellowing disease of coconut in Ghana
}

\author{
S. K. Dery ${ }^{1}$, J. Owusu-Nipah ${ }^{1}$, E. Andoh-Mensah ${ }^{1}$, B. N. Nuertey ${ }^{1}$, J. Nkansah-Poku ${ }^{1}$, \\ R. Arthur ${ }^{2}$ and R. Philippe ${ }^{3}$
}

\begin{abstract}
The performance of the coconut hybrid, Malayan Yellow Dwarf x Vanuatu Tall (MYD x VTT) was assessed in Ghana for a period of 6-8 years. The hybrid has previously been identified as being tolerant to the devastating lethal yellowing disease known in Ghana as Cape Saint Paul Wilt Disease (CSPWD). CSPWD is the most important coconut disease in Ghana. It has destroyed approximately 11,000 ha of coconut in Ghana, causing economic hardship to thousands of people. Mortality due to CSPWD during the trial period was only $1.0 \%$. The hybrid showed remarkable tolerance to CSPWD during the 8-year trial period. Mortality, inflorescence emergence and nut load depended largely on the level of farmers' commitment to basic management practices. In well maintained farms, the hybrid performed two to three times better compared to farms where maintenance was poor.
\end{abstract}

Key words: Coconut, LYD-tolerance, on-farm adaptive trial, management practices, MYD x TT, CSPWD.

${ }^{1}$ Coconut Research Programme, Oil Palm Research Institute, Box 245, Sekondi, Ghana. Cocopri@africaonline

${ }^{2}$ Coconut Sector Development Project, Ministry of Food and Agriculture, Box 245, Sekondi, Ghana.

${ }^{3}$ Cirad-CP, C/o Box 245, Sekondi, Ghana. Ciradcpgh@yahoo.fr 


\section{Introduction}

The Cape St Paul Wilt Disease (CSPWD) of coconut in Ghana is a lethal yellowing-type disease, caused by phytoplasma (Tymon et al., 1993). The disease was first observed in the country in 1932 at Cape St Paul near Woe in the Volta Region (Westwood, 1953). By 1964 it had spread from Cape St Paul to Cape Three Points in the Western Region. The disease then spread to the Central Region in 1984 when it was spotted at Ayensudo (about $35 \mathrm{~km}$ west of Cape Coast). As at 2002, the disease had devastated about 11,000 hectares of coconut farms in the Western, Central and Volta Regions (Anonymous, 2002) resulting in economic hardships to thousands of farmers whose livelihood depends on the crop.

Realizing the threat posed to the coconut industry, a screening programme was initiated in 1981 under the France-Ghana-Côte d'Ivoire Coconut Project to identify coconut varieties tolerant to the disease. A total of 27 coconut varieties were planted in 7 varietal screening fields established at 7 locations within the active zone of the CSPWD namely; Agona Nkwanta, Akwidae, Cape Three Points, Dixcove, Dadwen, Axim and Princess Town, all in the Western Region. The 27 varieties consisted of 5 dwarf ecotypes, 16 Dwarf $\mathrm{x}$ Tall hybrids, 5 tall $\mathrm{x}$ tall crosses and the local West African Tall variety. By 1994, the Malayan Yellow Dwarf x Vanuatu Tall (MYD x VTT) had been identified as a promising, tolerant hybrid (Dery et al., 1997). As part of the activities to develop and evaluate coconut progenies for high yield and tolerance to CSPWD started under the E.C. STD III Project (1993-97) and continued under the World Bank funded National Agricultural Research Project (1995-1999), field-testing of the tolerance of MYD x VTT to CSPWD was carried out in on farm adaptive trials under farmers' field conditions.

This paper assesses the performance of the hybrid in terms of mortality, inflorescence emergence and nut load in relation to farmers' management practices in the adaptive trials.

\section{Methodology}

The MYD x VTT hybrid for the field-testing was produced from MYD mother palms in the Aiyinase Seed Garden, located in the Nzema East District of Ghana through assisted pollination using VTT pollen procured from the Marc Delorme Research Station in Côte d'Ivoire. The resulting seed-nuts were sprouted in seedbeds and MYD x VTT hybrids selected based on colour of sprout. Selected sproutings were transferred into black polybags $(40 \mathrm{~cm} \times 40 \mathrm{~cm}$ layflat and $0.2 \mathrm{~mm}$ thick) and raised for 8 months before distribution to farmers. In all 33 farmers located within the active zone of the CSPWD were selected. Each farmer was given 120 seedlings to plant at $8.5 \mathrm{~m}$ triangular spacing under the supervision of Agricultural Extension Agents in May 1996. Replacement of dead seedlings in the farms was done for two years (up to May 1998). Management of the trials were however left to the farmers with minimal support (provision of wire net and watering facilities). Although 33 adaptive trials were initially set up, 14 farmers neglected their farms. The remaining 19 were therefore used for the performance assessment (Table 1). These were distributed over the 3 coconut growing regions in Ghana: 8 in central, 5 in western and 6 in volta regions. The location of these trials (see map) varied from the coastline (along the seashore), off-coastline (within $5 \mathrm{~km}$ from the seashore) to inland (beyond $5 \mathrm{~km}$ offcoastline). Observations and assessment visits were made every six months during which dead palms due to CSPWD or other factors as well as flowering and non-flowering palms were recorded. The farmers were also interviewed on management practices carried out in the trials. Nut count was done on the flowering palms in February 2004. Nuts in the bunch of leaf ranks 14, 19 and 24 were counted separately and averaged. The mean number of nuts was multiplied by 12 months to estimate annual nut load per palm. 
Table 1. The 19 MYD x VTT adaptive trials used for performance assessment

\begin{tabular}{|c|c|c|c|c|}
\hline \multirow{2}{*}{ Region } & \multirow{2}{*}{$\begin{array}{l}\text { Trial } \\
\text { No. }\end{array}$} & \multicolumn{3}{|c|}{ Location } \\
\hline & & Coastline (CL) & Off-coastline (OC) & Inland (IL) \\
\hline \multirow[t]{5}{*}{ Western } & 1 & & Feanza & \\
\hline & 2 & & & Daboase Junction \\
\hline & 3 & & Bronikrom & \\
\hline & 4 & & & Banso \\
\hline & 5 & & & Anto \\
\hline \multirow[t]{8}{*}{ Central } & 6 & Brenu-Akyinim & & \\
\hline & 7 & Narkwa & & \\
\hline & 8 & & Ayensudo & \\
\hline & 9 & & & Eduma \\
\hline & 10 & & & Eduma \\
\hline & 11 & & & Benyadze \\
\hline & 12 & & & Dompoase \\
\hline & 13 & & & Emisakrom \\
\hline \multirow[t]{6}{*}{ Volta } & 14 & Vui-Tegbi & & \\
\hline & 15 & Woe & & \\
\hline & 16 & Keta & & \\
\hline & 17 & Woe & & \\
\hline & 18 & Woe & & \\
\hline & 19 & Woe & & \\
\hline
\end{tabular}

Management practices carried out by the farmers were weed control, Oryctes picking and watering of seedlings during dry spells.

\section{Results and discussion}

\section{Results}

\section{Management practices}

The level of farmers' commitment to weed control, Oryctes picking and watering of seedlings during dry spells varied considerably in the 19 trials (Table 2). The trials were not fertilized but some were intercropped during the first 2-3 years after planting.

\section{Performance of MYD $x$ VTT as influenced by management practices}

Coastline (CL) adaptive trials in the Central (C) and Volta (V) Regions

The mortality rate in trial number 17 [CL, V] was $25.0 \%$, with $43.3 \%$ of the initial seedlings planted carrying a mean annual load of 96 nuts per palm. Trial $\mathrm{n}^{\circ} 17[\mathrm{CL}, \mathrm{V}]$ was watered many times in addition to Oryctes picking and weed control (Table 2). In trials 15 [CL, V] and 18 $[\mathrm{CL}, \mathrm{V}]$, which were managed the same way as 17 but scarcely watered, death rate was $84.2 \%$ (more than 3-fold higher compared with 25\% mortality in trial $\left.n^{\circ} 17\right)$. However, in trial $n^{\circ} 16$ $[\mathrm{CL}, \mathrm{V}]$ which was watered a few times with Oryctes picking and weed control, mortality was $49.2 \%$ with $30.8 \%$ of the initial seedlings planted bearing nuts at mean annual load of 92.8 per palm (Table 2). 
Table 2. Effect of management practices on the performance of MYD x VTT as on February 2004

\begin{tabular}{|c|c|c|c|c|c|c|c|c|}
\hline \multirow{2}{*}{$\begin{array}{c}\text { Trial } \\
\text { No. }\end{array}$} & \multirow[t]{2}{*}{ Location } & \multicolumn{3}{|c|}{ Management practices } & \multicolumn{4}{|c|}{ Performance } \\
\hline & & $\begin{array}{c}\text { Weed } \\
\text { control }\end{array}$ & $\begin{array}{l}\text { Seedling } \\
\text { watering }\end{array}$ & $\begin{array}{l}\text { Oryctes } \\
\text { picking }\end{array}$ & $\begin{array}{l}\text { Live } \\
\text { palms } \\
\text { (No.) }\end{array}$ & $\begin{array}{c}\% \\
\text { Flowering }\end{array}$ & $\begin{array}{c}\text { Annual } \\
\text { nut load } \\
\text { per palm }\end{array}$ & $\begin{array}{c}\% \\
\text { Mortality }\end{array}$ \\
\hline 1 & Feanza (OC) & ++ & 0 & ++ & 98 & 79.2 & 95.2 & 18.3 \\
\hline 2 & Daboase Junction (IL) & ++ & 0 & ++ & 91 & 70.8 & 70.7 & $25(1)^{*}$ \\
\hline 3 & Bronikrom (OC) & ++ & 0 & ++ & 114 & 90.0 & 93.3 & $5.8(1)^{*}$ \\
\hline 4 & Banso ( IL ) & -- & 0 & -- & 47 & 3.3 & 68.3 & 60.8 \\
\hline 5 & Anto (IL) & ++ & 0 & ++ & 87 & 58.3 & 91.2 & 27.5 \\
\hline 6 & Brenu-Akyinim (CL) & \pm & -- & \pm & 32 & 13.3 & - & 73.3 \\
\hline 7 & Narkwa (CL) & -- & -- & -- & 10 & 0 & - & 91.7 \\
\hline 8 & Ayensudo (OC) & ++ & 0 & ++ & 114 & 87.5 & 129.4 & 3.3 \\
\hline 9 & Eduma (IL) & ++ & 0 & ++ & 114 & 90.0 & 100.2 & 5.0 \\
\hline 10 & Eduma (IL) & \pm & 0 & \pm & 65 & 40.0 & 113.4 & 45.8 \\
\hline 11 & Benyadze (IL) & \pm & 0 & \pm & 60 & 14.2 & 72.6 & 50.0 \\
\hline 12 & Dompoase (IL) & ++ & 0 & ++ & 111 & 85.0 & 119.0 & 7.5 \\
\hline 13 & Emisakrom (IL) & \pm & 0 & \pm & 31 & 0.8 & - & 74.2 \\
\hline 14 & Vui-Tegbi (CL) & ++ & ++ & ++ & 94 & 71.7 & 112.8 & $22.5(1)^{*}$ \\
\hline 15 & Woe (CL) & + & -- & + & 29 & 14.2 & 86.4 & 77.5 \\
\hline 16 & Keta (CL) & \pm & \pm & \pm & 61 & 30.8 & 92.8 & 49.2 \\
\hline 17 & Woe (CL) & + & + & + & 90 & 43.3 & 96.0 & 25.0 \\
\hline 18 & Woe (CL) & + & -- & + & 11 & 6.7 & 96.6 & 90.8 \\
\hline 19 & Woe (CL) & \pm & -- & \pm & 9 & 0 & - & 92.5 \\
\hline $\begin{array}{l}(++)= \\
(\mathrm{CL})= \\
*(1) \mathrm{C}\end{array}$ & $\begin{array}{l}\text { quently }(+)=\text { Man } \\
\text { stline }(\mathrm{OC})=\text { Off-c } \\
\text { f the palms was kille }\end{array}$ & $\begin{array}{r}( \pm)= \\
\text { e }(\mathrm{IL}) \\
\text { thal ye }\end{array}$ & $\begin{array}{l}\text { times (--) } \\
\text { lland } \\
\text { ing disease }\end{array}$ & Scarcely & $0)=\mathrm{Nil}$ & & & \\
\hline
\end{tabular}


In trials $6[\mathrm{CL}, \mathrm{C}]$ and $19[\mathrm{CL}, \mathrm{V}]$, which were managed the same way as 16 but scarcely watered, death rate was $82.9 \%$ (nearly double, compared with $49.2 \%$ death rate in trial $\mathrm{n}^{\circ} 16$ ). Trial $\mathrm{n}^{\circ} 7[\mathrm{CL}, \mathrm{C}]$ was scarcely watered nor were Oryctes and weeds controlled. Therefore mortality rate was as high as $91.7 \%$. In contrast, trial $\mathrm{n}^{\circ} 14[\mathrm{CL}, \mathrm{V}]$ was frequently watered, in addition to frequent Oryctes picking and weed control. Consequently, death rate was only $22.5 \%$ with $71.7 \%$ of the initial seedlings bearing nuts at mean annual load of 112.8 per palm (Fig.1).

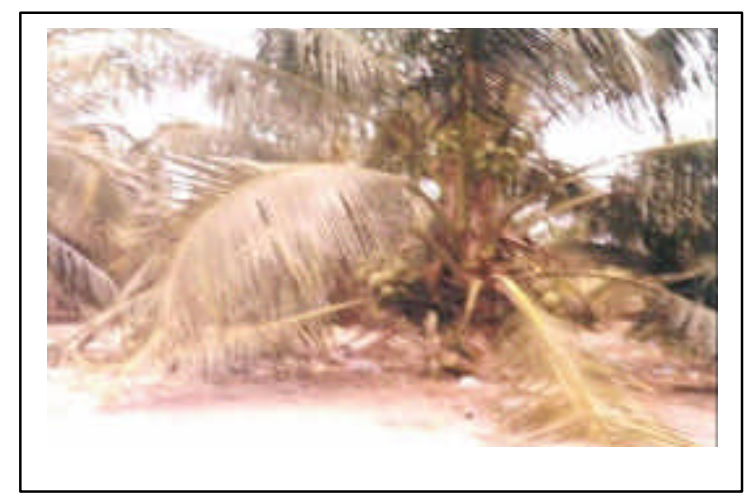

Fig. 1. Hybrid seedlings in trial No. 14

\section{Off-coastline (OC) and inland (IL) adaptive trials in the Western $(\mathrm{W})$ and Central Regions}

Trials 1 and 3 [OC, W], 2 and 5 [IL, W], 8 [OC, C], 9 and 12 [IL, C] were more or less uniform in performance. The seven trials above had frequent control of Oryctes and weeds but were not watered (Table 2). As a result average mortality was low, $13.2 \%$ with $80.1 \%$ of the initial seedlings planted carrying a mean annual load of 99.9 nuts per palm. For trial numbers 10 and 11 [IL, C] which had Oryctes and weeds controlled only a few times, death rate was $47.7 \%$ (nearly 4-fold higher compared with $13.2 \%$ death rate in trials with frequent control of Oryctes and weeds). About $27.1 \%$ of the initial seedlings planted were fruiting with a mean annual load of 93 nuts per palm. Trial number 4 [IL, W] scarcely had any Oryctes or weeds controlled. Mortality rate was $60.8 \%$ with $3.3 \%$ of the seedlings planted bearing nuts at mean annual load of 68.3 per palm.

\section{Performance of MYD $x$ VTT in relation to CSPWD incidence}

The mortality rate due to CSPWD in the trials was only $1 \%$. Only 3 palms: one each in three farms (trials 2, 3 and 14) died of CSPWD. This was confirmed by PCR analysis. The three trials were located inland, off-coastline and coastline respectively.

\section{Discussions}

The considerable variation in the level of farmers' commitment to basic management practices in the adaptive trials was reflected in the substantial differences observed in the hybrid performance. The wide variation in the farmers' commitment could be attributed to a number of factors such as labour difficulties, lack of support package, crop advantage of other tree crops over coconut especially in the inland and fishing activities along the coastline. Intercropping the hybrid with food crops within the first three years of planting could have motivated the less committed farmers to ensure regular maintenance (Reynolds, 1988).

Mortality due to CSPWD over the period of assessment was only $1 \%$. This obviously is a very good performance and an indication of the tolerance of MYD x VTT to CSPWD. The major mortality factors were moisture stress, weed competition and Oryctes damage. The former was the most prominent factor influencing mortality and flowering of MYD x VTT coconut hybrid in the coastline trials. This was indicated by the fact that mortality increased from $22.5 \%$ in frequently watered trials to $85.2 \%$ in scarcely watered trials. Flowering rate also increased from $6.8 \%$ in scarcely watered trials to $71.7 \%$ in frequently watered trials.

The littoral sandy soils have low water holding and high heating capacities, which result in severe moisture and thermal stress during dry weather (Fig. 2). Without supplementary 
watering, prolonged moisture stress during long dry spells could stagnate growth and development or even be lethal to the hybrid (FAO, 1975; Bourdeix, 1999). The nut load per palm however seemed unaffected by the supplementary watering probably because the mature palms are able to tap the abundant subterranean water, a result of tidal action.

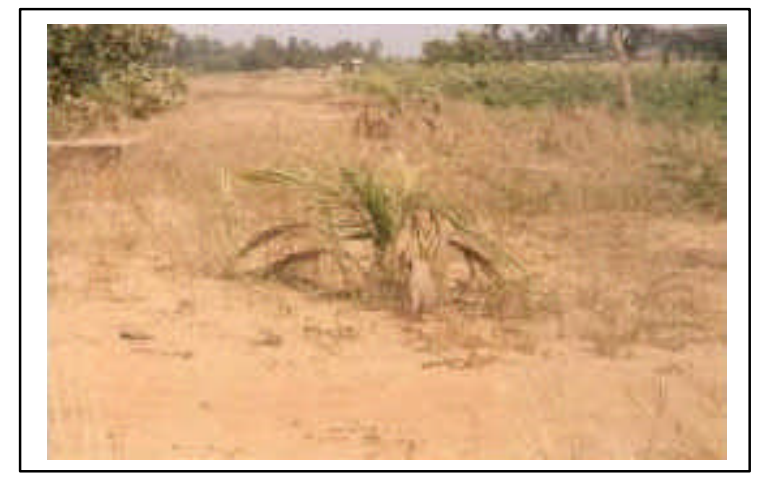

Fig. 2. Moisture stressed hybrid seedlings

In the off-coastline and Inland adaptive trials of the western and central regions, weed competition (Fig. 3) and Oryctes attack (Fig. 4) were notable in influencing mortality, flowering and nut yield of the hybrid: Death rate increased from $13.2 \%$ in well-maintained trials to $60.8 \%$ in scarcely maintained trials. Flowering rate and annual nut load also increased from $3.3 \%$ and 68.3 nuts per palm in the latter to $80.1 \%$ and 99.9 per palm in the former. Young plantings of MYD x VTT was observed by Bonneau et al., 2002 to be quite susceptible to weed competition. Besides, weeds provide congenial environment for rodent attack (Appiah and Attuquayefio, 2000).

Damage caused by Oryctes attack adversely affected growth and development of young coconut palms (Fig. 4) and in some cases led to death. The considerable mortality rate of $13-23 \%$ in well-maintained adaptive trials notwithstanding frequent Oryctes picking and weed control and also supplementary watering in the case of coastline trials, suggests that there were other mortality factors of which termite attack was prominent $(\mathrm{R}$. Philippe, personal communication).

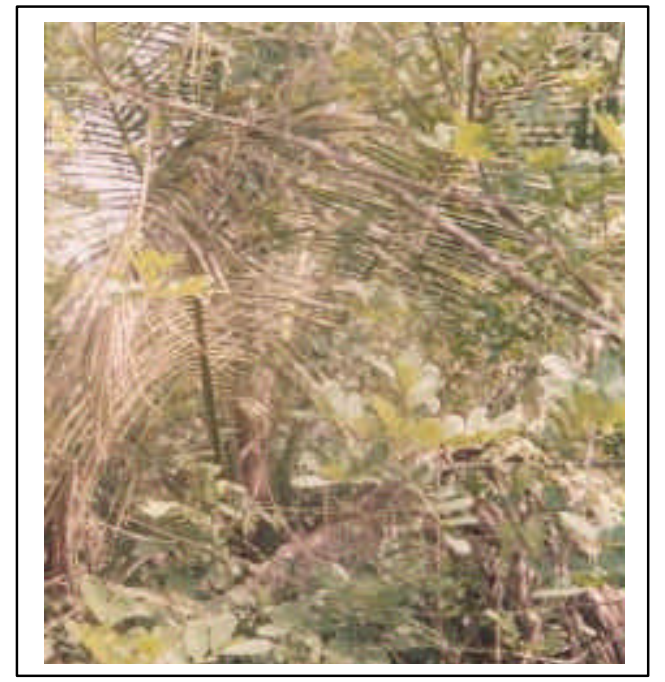

Fig. 3. Hybrid seedlings in serious competition with weeds

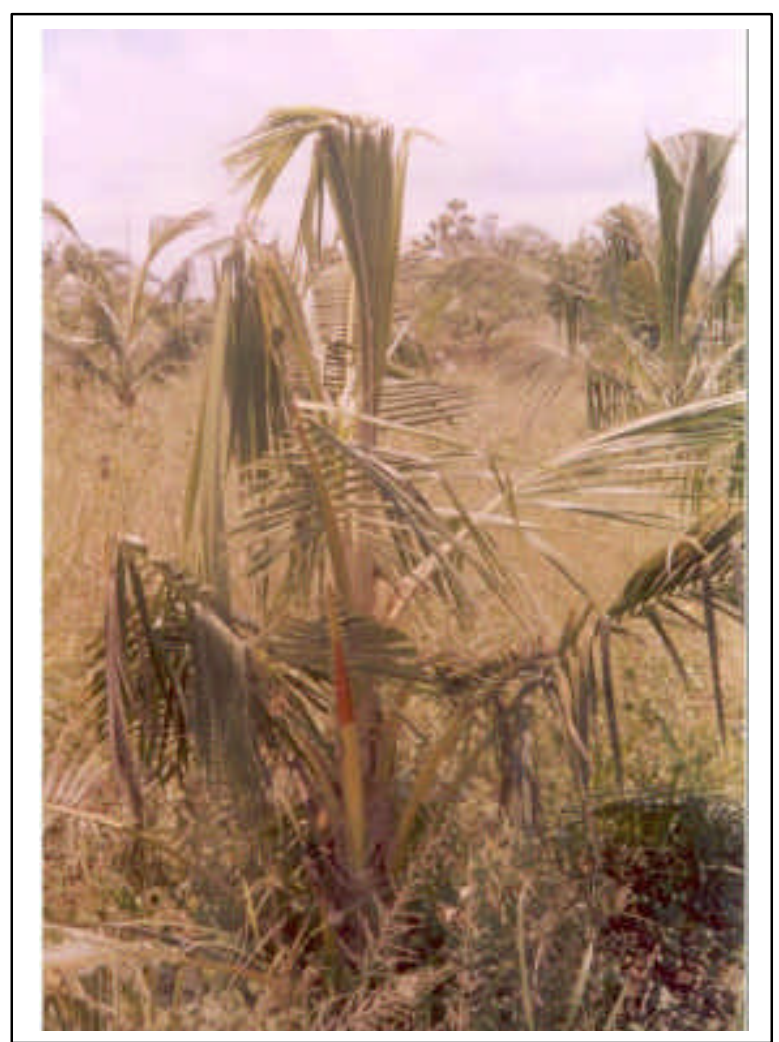

Fig. 4. Oryctes attacks causing damages to palm 
On-farm adaptive trials especially those managed by farmers are usually difficult to analyse scientifically due to large variability in the management of the farms. In this particular case 14 farms, which were totally neglected, could not be included in the analyses. However, after 8 years of observation, mortality due to CSPWD was only $1 \%$. It is also important to point out that although one palm each in 3 farms got infected by CSPWD, no disease foci could be formed around those infections as described by Dery et al. (1999). This again reinforces our belief that MYD x VTT does have some degree of tolerance to the CSPWD. It is important, though, to continue the screening for resistance to CSPWD since resistance/tolerance can break down with time.

\section{Acknowledgement}

We wish to acknowledge the financial support given by EEC STD III Project and the National Agricultural Research Project (NARP). This paper is published with the permission of the Director of the Oil Palm Research Institute (OPRI), Kusi.

\section{References}

Anonymous, 2002. CSIR - Oil Palm Res. Inst. Ann. Report 2001.

Appiah, S. O. and Attuquayefio, D. K. 2000. Assessment and comparison of current rodent control techniques towards the protection of young oil palm (Elaies guineensis) in the field. J. Ghana Sci. Assoc. 2 (2): 99-106.

Bonneau, X., Dery S. K. and Andoh-Mensah, E. 2002. Agronomist mission report to the Coconut Sector Development Project; $21^{\text {st }}$ April to $5^{\text {th }}$ May 2002. CIRAD-CP Doc. CPSIC 1497, Montpellier, France, pp. 15-16

Bourdeix, R. 1999. Coconut Varieties: Malayan Dwarf. Cogent Newsletter, Issue 2, Oct. 1999, pp. 13-15
Dery, S. K., N'Cho, Y.P., Sangare, A. and Arkhurst, E. D. 1997. Cape Saint Paul Wilt disease: Resistance screening and prospects for rehabilitating the coconut industry in Ghana. In: Proceedings of an International Workshop on Lethal Yellowing-like Disease of Coconut, S. J. Eden-Green and F. Ofori (Eds.), Elimina, Ghana, November 1995. Chatman, U. K. Natural Resources Institute, pp. $147-152$

Dery, S. K., Nkansah - Poku, J. and Philippé, R. 1999. The history and epidemiology of Cape St. Paul Wilt disease of coconut in Ghana. $J$. Ghana Sci. Assoc. 1(2) 32-42.

FAO 1975. Coconut Palm Products: Their Processing in Developing Countries. B. E. Grimmwood (Ed.), Tropical Products Institute, London, pp. 6-29

Philippé, R. personal and communication. Philippé, $\mathrm{R}$ is a senior Research Entomologist of CIRAD - CP, Montpellier attached to the Coconut Research Programme, Sekondi, Ghana.

Reynolds, S. C. 1988. Advantages and disadvantages of intercropping coconut. In: Pasture and Cattle under Coconut. FAO Pasture Production and Protection Paper 91, Rome.

Tymon, A., Jones, P. and Eden - Green, S. J. 1993. Detection and description of mycoplasmalike organisms associated with coconut lethal yellowing and other disease. N.R.I. Proj. A0282, Final Technical Report R.2970 (S), $21 \mathrm{pp}$.

Westwood, D. 1953. Coconut diseases, Keta, Goldcoast. Ghana Farmer, 2(1) 